\title{
Influence of the placement rate on the fresh concrete lateral pressure in the design of formworks
}

\section{Influência da velocidade de concretagem sobre a pressão lateral do concreto fresco no dimensionamento de fôrmas}
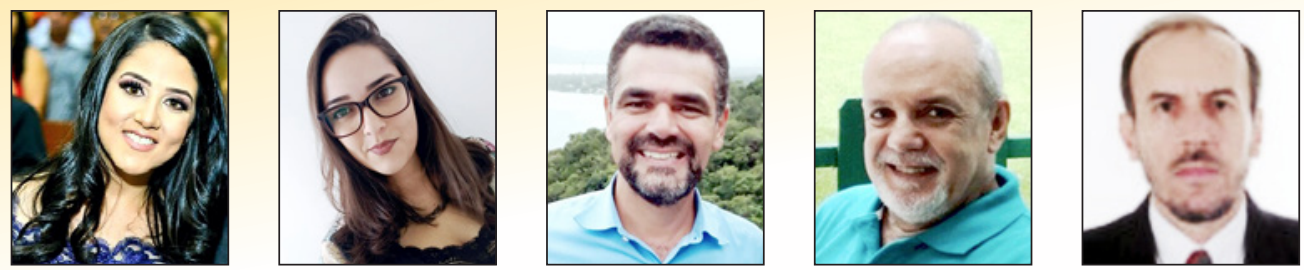

M. O. SOUSA a

sousa.marinaeng@gmail.com

N. S. SANTOS

naianeengcivil@gmail.com

R. L. PEREIRA

robsonlopesvetor@gmail.com

P. C. R. MARTINS d

profpaulochaves@gmail.com

L. J. PEDROSO

lineujp@gmail.com

\begin{abstract}
The fresh concrete lateral pressure generates a load that has great influence in the design of the formworks of columns, walls and lateral faces of the beams. Its prediction must be performed in such a way in order to approach precisely well over the rate values supported by the formworks, avoiding, therefore, the oversizing or undersizing of these temporary structures which represent up to $12 \%$ of the total cost of the construction. The calculation of the lateral pressure that fresh concrete exerts on the formworks involves several variables; one of them is the placement rate. The main objective of this work was to study the influence of the placement rate, in situ, on the lateral pressure of fresh concrete calculated from theoretical models presented by norms and international references. For this purpose, measurements of the placement rate were conducted on columns of five building work places at Goiânia city, Goiás, Brazil and it was calculated the maximum pressure supported by their respective formworks from the dimensions and spans between the supports of the components that constituted them. The obtained results indicate that the placement rate in the field observations reach $249 \mathrm{~m} / \mathrm{h}$, exceeding the values limited by the theoretical methods of calculation, and that the lateral pressure estimation produced from the placement rate measured in situ exceed the maximum values supported by the formworks up to 604 times. Thus, it was concluded that it is necessary to adjust equations to estimate the lateral pressure of fresh concrete at high rate of concrete placement, according to the current practices in the construction market.
\end{abstract}

Keywords: lateral pressure, formworks, columns, placement rate.

\section{Resumo}

A pressão lateral do concreto fresco gera uma carga que possui grande influência no dimensionamento das fôrmas de pilares, paredes e faces laterais das vigas. Sua previsão deve ser realizada de modo que se aproxime bem dos valores suportados pelas fôrmas, evitando-se, assim, o superdimensionamento ou subdimensionamento dessas estruturas provisórias que representam até $12 \%$ do custo total da obra. O cálculo da pressão lateral que o concreto fresco exerce sobre as fôrmas envolve diversas variáveis, sendo uma delas a velocidade de concretagem. O principal objetivo deste trabalho foi estudar a influência da velocidade de concretagem sobre a pressão lateral do concreto fresco calculada a partir de modelos teóricos apresentados por normas e referências internacionais. Para isso, foram realizadas medições da velocidade de concretagem em pilares de cinco obras de Goiânia e calculadas as pressões máximas suportadas por suas respectivas fôrmas, a partir das dimensões e dos vãos entre os apoios dos elementos que as constituíam. Os resultados obtidos apontam que as velocidades de concretagem em campo chegam a $248,57 \mathrm{~m} / \mathrm{h}$, superando os valores limitados pelos métodos teóricos de cálculo, e que as estimativas da pressão realizadas a partir das velocidades medidas in loco ultrapassam os valores máximos suportados pelas fôrmas em até 603,75 vezes. Assim, concluiu-se que é necessária a formulação de equações para estimar a pressão lateral do concreto fresco a altas velocidades de concretagem, conforme as atuais práticas no mercado da construção civil.

Palavras-chave: pressão lateral, fôrmas para concreto, pilar, velocidade de concretagem.

a, b, c Pontifícia Universidade Católica de Goiás, Escola de Engenharia, Goiânia, GO, Brasil,

$c, d$, e Universidade de Brasilia, PECC-UnB, Brasilia, DF, Brasil.

Received: 21 Jun 2017 • Accepted: 26 Sep 2017 • Available Online:

This is an open-access article distributed under the terms of the Creative Commons Attribution License 


\section{Introduction}

The reinforced concrete is one of the most consumed materials in civil construction, and currently it is one of the most substantial materiel in this area of engineering. For its application it is necessary to use formworks and shoring, which, in accordance with Freitas [1], have the function of guaranteeing the geometry, the level and the alignment of the structural element to be executed. Despite the importance of the formworks and shoring, there is, in accordance with Rezende [2], a misguided neglect with this interim structural system, occurring, in particular situations, the lack of specific design and even the absence of engineer in the execution of this design.

For Nazar [3], a detailed study, the design as well as the correct choice of the materials of the formworks and shoring are justified by their importance in the conception, of the building during their execution and the costs of the building structure. For residential and commercial buildings with multiple pavements, the time for the execution of the formworks and the shoring can alternate between $50 \%$ and $60 \%$ of the total time for the execution of the work. Maranhão [4] alleges that the cost of the formworks contributes about $40 \%$ to $60 \%$ of the total cost of the reinforced concrete structure, which is, in approximate numbers, an item that answers between $8 \%$ and $12 \%$ of the cost of a building work.

In accordance with Barnes and Johnston [5] and Maranhão [4], the prediction of the fresh concrete lateral pressure must be made for the design of vertical formworks (columns, walls and beams with vertically straighten faces), to ensure safety and minimize costs. Maranhão [4] asserts that there are plenty of variables that influence on the magnitude of the fresh concrete lateral pressure. Therefore, studies and tests conducted to determine a suitable equation to solve the problem differ greatly over the results.

The placement rate is one of the variables that exert greatest effect on fresh concrete lateral pressure. Zahng et al. [6], in their empirical research with conventional concretes (compacted by vibration), ob-

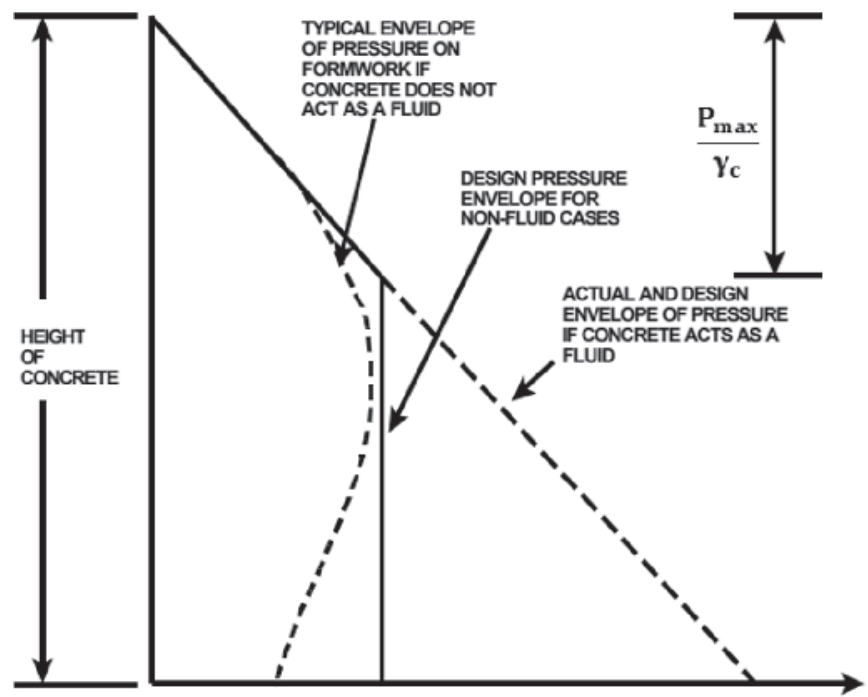

Figure 1

Fresh concrete lateral pressure envelopes

Source: Adapted from Barnes and Johnston [5] tained results that confirmed what is proposed by several calculation methods: placement rate directly affects the lateral pressure and the higher the values of this variable, the greater is the pressure exerted by the concrete. Santilli et al. [7] observed in their study that placement rate and temperature are significant for estimating the fresh concrete lateral pressure, since these variables appear implicitly or explicitly in all the equations of the eight theories they studied.

For Leemann et al. [8], increasingly higher placement rate values are used to reduce construction periods and are commonly expected to exceed $10 \mathrm{~m} / \mathrm{h}$. Notwithstanding, the current standards for the pressure prediction of conventional concrete were designed mainly for lower placement rate values, becoming necessary to determine an appropriate equation to estimate the maximum lateral pressure of the fresh concrete placed at high rates.

Amongst the calculation methods of fresh concrete lateral pressure it can be verified the models proposed by the American Concrete Institute ( $\mathrm{ACl})$, Construction Industry Research and Information Association (CIRIA) and the Associação Brasileira de Normas Técnicas (ABNT - Brazilian Association of Technical Norms - BATN), which will be methods studied in this report.

This research had as main ambition to study the placement rate as a factor that influences the fresh concrete lateral pressure on the formworks. It was verified if the placement rate values performed in constructions from Goiânia are representative of the values limited by the methods of calculation ACI 347 R-04, CIRIA R 108 e ABNT NBR 15696:2009 and if the pressure calculated by the methods ACI 347 R-04, CIRIA R 108 e ABNT NBR 15696:2009, from the placement rate values documented in situ approximate the maximum pressure values supported by the columns formworks.

\subsection{Justification}

The calculation of the fresh concrete lateral pressure is of great seriousness for the formworks and shoring design, insofar as, for vertical formworks, mainly columns and walls, the load which is resulted from this tension has considerable influence on their design, which interferes directly with the quantitative of material and, consequently, over the cost of the concrete structure. The literature presents the placement rate as one of the variables that more impacts over the result of the fresh concrete lateral pressure calculation, and it should be limited to a determined value, as specified by some methods, not often being agreeable with the reality of the contemporary constructions. Furthermore, until the ABNT NBR 15696:2009, there was not, in Brazil, another normative guideline for the formworks and shoring design, being, therefore, not widely analyzed by the national engineering sciences.

\section{Fresh concrete lateral pressure}

The NBR 15696 [9] defines the fresh concrete lateral pressure as the horizontal pressure that the concrete exerts on the face of the formwork which is in contact with it.

Barnes and Johnston [5] assure that the concrete lateral pressure exerted on the formworks is often lower than the hydrostatic pressure, which considers the concrete an unit weight close to $24 \mathrm{kN} / \mathrm{m}^{3}$, and a calculated pressure for the design of its formworks, as showed in Figure 1. 
In accordance with Barnes and Johnston [5], there are several factor that affect the magnitude of the fresh concrete lateral pressure, including concrete induration, placing procedure and internal friction between granular components of the concrete with the internal faces of the formworks, which makes it arduous to establish an equation that represents the typical envelope of the fresh concrete pressure, i.e., the actual lateral pressure distribution curve, represented in Figure 1. In order to streamline this problem, most of the formworks design methods characterize the pressure as hydrostatic up to a certain distance below the free surface of concrete and these methods admit that, from this point, it remains constant until the base of the formwork with maximum value predicted by the calculation standard, as presented in Figure 1.

The placement rate $(\mathrm{m} / \mathrm{h})$ is one of the variables used in the determination of the fresh concrete lateral pressure, being this factor, in accordance with NBR 15696 [9], "o incremento vertical do nível superior do concreto medido linearmente em relação ao tempo decorrido de concretagem" ('the vertical increment of the concrete upper level measured linearly in relation with the elapsed time of placing"). Cauberg et al. [10], to present the values obtained in their empirical study of fresh concrete lateral pressure, exemplify: a placement rate of $10 \mathrm{~m} / \mathrm{h}$ implies a filling of a 4 meters column formwork in 24 minutes and a rate of $5 \mathrm{~m} / \mathrm{h}$ requires, for the same column formwork, twice as long.

Maranhão [4] presented, in his report, the results of the studies carried out by the Laboratório de Madeiras e Estruturas de Madeiras (LaMEM - Wood and Wood Structures Laboratory), from the Structural Engineering Department from the School of Engineering of São Carlos - USP (University of São Paulo, Brazil), which indicate the placement rate and concrete consistency as the parameters that have most influenced the fresh concrete lateral pressure value.

Differently, Billberg et al. [11], based on the fresh concrete lateral pressure gauged through field research, concluded that in the case of the self-consolidating concrete, other causes may be more relevant than the placement rate, due to the low correlation between this parameter and the maximum relative lateral pressure (predicted rate between the measured pressure and hydrostatic pressure). The lack of correlation between the pressure and the placement rate displays that the self-consolidating concrete structural behavior at rest must be considered in the prediction of the lateral pressure on the formworks.

\subsection{Theoretical models for fresh concrete lateral pressure calculation}

\subsubsection{ACI 347 R-04}

The equations from $\mathrm{ACl} 347 \mathrm{R}-04$ [12] for the determination of maximum fresh concrete lateral pressure $\left(P_{\max }\right)$ are credible for slump concrete with a $175 \mathrm{~mm}$ maximum, compacted with normal internal vibration to a depth of 1.2 meter or less.

For all types of columns and for walls with placement rate lower than $2.1 \mathrm{~m} / \mathrm{h}$ and placing height (h) that would not exceed $4.2 \mathrm{~m}$, $\mathrm{P}_{\text {max }}(\mathrm{kPa})$ it is disposed the equation (1).

$P_{\text {max }}=C_{w} C_{C}\left[7.2+\frac{785 R}{T+17.8}\right]$
Where $C_{w}$ is the unit weight coefficient, $C_{c}$ is the concrete chemistry coefficient, $R$ is the placement rate in $\mathrm{m} / \mathrm{h}$ and $\mathrm{T}$ is the temperature of the concrete in ${ }^{\circ} \mathrm{C}$

For walls with $R<2.1 \mathrm{~m} / \mathrm{h}$ and $\mathrm{h}>4.2 \mathrm{~m}$ and all walls with $2.1 \mathrm{~m} / \mathrm{h}<\mathrm{R}<4.5 \mathrm{~m} / \mathrm{h}, \mathrm{P}_{\max }(\mathrm{kPa})$ it is recommended the equation (2).

$P_{\max }=C_{w} C_{C}\left[7.2+\frac{1156}{T+17.8}+\frac{224 R}{T+17.8}\right]$

For the equations (1) and (2), $30 \mathrm{C}_{\mathrm{w}} \leq \mathrm{P}_{\max } \leq \rho g h$.

\subsubsection{CIRIA R 108}

The CIRIA R 108 report provides guidance for fresh concrete lateral pressures calculation on the formworks. In accordance with Waarde [13], the maximum pressure $\left(P_{\max }\right)$, in $\mathrm{kPa}$, that the fresh concrete exerts on the formworks, determined from the CIRIA $R$ 108 method, it is calculated from equations (3) e (4), being recommended to be taken, for the design, the smaller value obtained.

$P_{\text {max }}=\gamma_{c}\left[C 1 \sqrt{v}+C_{2} K \sqrt{H-C 1 \sqrt{v}}\right]$

$P_{\text {max }}=\gamma_{c} \cdot h$

where $\gamma_{c}$ is the unit weight of the concrete $\left(\mathrm{kN} / \mathrm{m}^{3}\right), \mathrm{C} 1$ is the coefficient that depends on the size and shape of the formworks ( 1 for walls e 1.5 for columns), $C_{2}$ is the coefficient that depends on the constitutive materials of the concrete, $v$ is the placement rate in $\mathrm{m} / \mathrm{h}, \mathrm{K}$ is the temperature coefficient, $\mathrm{H}$ is the height of the formworks in meters and $\mathrm{h}$, the placing height in meters. The coefficient $\mathrm{K}$ is calculated by the equation (5).

$K=\left(\frac{36}{T+16}\right)^{2}$

Where $\mathrm{T}$ is equal the concrete temperature in ${ }^{\circ} \mathrm{C}$.

It is emphasized that the CIRIA R 108 does not appoint a limited value for placement rate, when $C 1 \sqrt{v}>H$, the equation (4) must be maintained as pressure of the design, in accordance with the description Waarde [13].

\subsubsection{NBR 15696 (ABNT, 2009)}

The maximum fresh concrete lateral pressure calculus proposed by NBR 15696 [9] is used for different classes of concrete consistency, the consistency classes are determined in accordance with Table 1.

\section{Table 1}

Concrete consistency classes

\begin{tabular}{|c|c|}
\hline Consistency class & Slump $(\mathbf{m m})$ \\
\hline C1 & slump $\leq 20$ \\
\hline C2 & $20<$ slump $\leq 80$ \\
\hline C3 & $80<$ slump $\leq 140$ \\
\hline C4 & slump $>140$ \\
\hline Source: NBR 15696 [9] \\
\hline
\end{tabular}



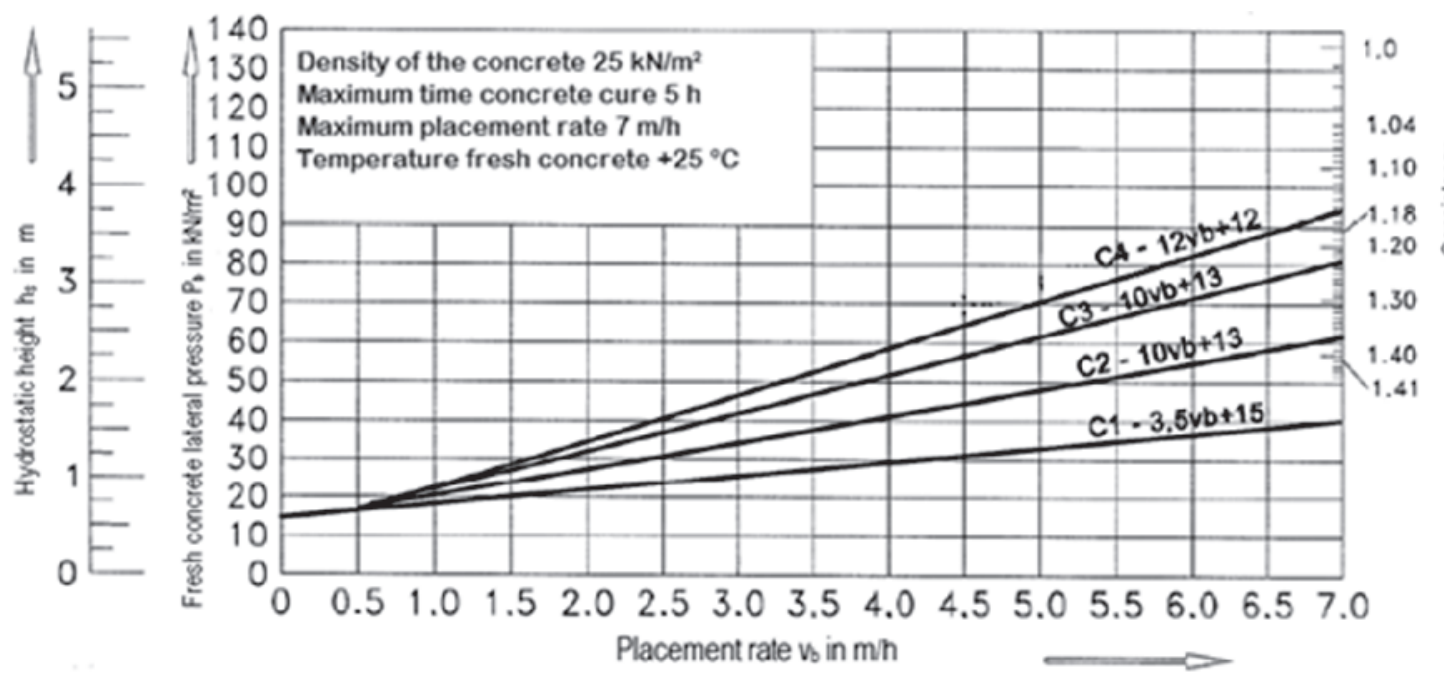

\section{Figure 2}

Diagram for fresh concrete lateral pressure and the corresponding hydrostatic height determination, from the placement rate and its consistency

Source: Adapted from NBR 15696 [9]

In accordance with NBR 15696 [9] the hydrostatic height, represented by $\mathrm{P}_{\max } / \gamma_{c}$ in Figure 1, "is the difference between the upper surface of the fluid concrete and the height where the pressure of the fluid concrete reaches the maximum value".

The maximum fresh concrete lateral pressure $\left(P_{b}\right)$, in $\mathrm{kN} / \mathrm{m}^{2}$, and the corresponding hydrostatic height $\left(\mathrm{h}_{\mathrm{s}}\right)$, in meters, are predicted in accordance with the placement rate $\left(\mathrm{v}_{\mathrm{b}}\right)$, in $\mathrm{m} / \mathrm{h}$, and with the concrete consistency class, through the diagram presented in Figure 2.

When retardant additives are used, the values of the concrete pressure and the hydrostatic height, extracted from de diagram, must be multiplied by the increasing factors, which rely on the consistence class of the concrete and the time delay of the initial setting time in hours.

In the circumstance of self-consolidate concrete, due to its high fluidity, the pressure of the concrete must be considered as being

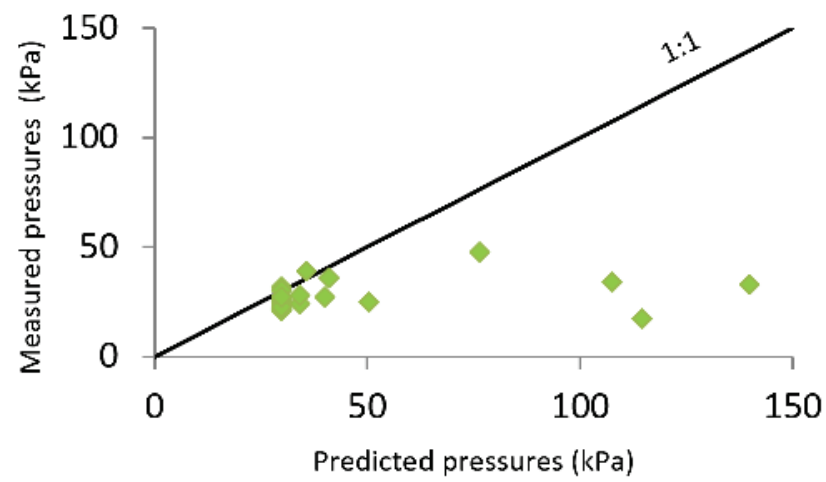

\section{Figure 3}

Lateral pressures predicted with the ACl 347 R-04 method versus measured lateral pressures for placement rate between 0.45 and $6.38 \mathrm{~m} / \mathrm{h}$ source: created by the authors hydrostatic, during the time of its induration or initial settings, depending on the method of placing.

If the unit weight of the concrete $\left(\gamma_{c}\right)$ alter from $25 \mathrm{kN} / \mathrm{m}^{3}$, the concrete pressure value ought to be multiplied by the factor $\alpha$, which differs according to the value of $\gamma_{c}$. The hydrostatic height remains the same regardless the specific weight changes.Supposing that there are no thermal isolation measures, the influence of temperature should be contemplated. It is not granted to contemplate temperatures above $25^{\circ} \mathrm{C}$. On the situations where the concrete temperature, during the placing, is less than $25^{\circ} \mathrm{C}, \mathrm{P}_{\mathrm{b}}$ and $\mathrm{h}_{\mathrm{s}}$ it should be increased by $3 \%$ for every $1{ }^{\circ} \mathrm{C}$ below $25^{\circ} \mathrm{C}$. The influence of temperatures above 25 ${ }^{\circ} \mathrm{C}$ is not allowed. The influence of temperatures above $25{ }^{\circ} \mathrm{C}$ is not allowed.

\subsection{Analysis of theoretical methods of calculating the fresh concrete lateral pressure}

The analysis of the prediction methods ACI 347 R-04, CIRIA R 108 and ABNT NBR 15696:2009 were conducted by comparing the fresh concrete lateral pressure estimated by these standards to empirical values presented by the authors: Arslan [14], Arslan et al. [15], Maranhão [4], O'Janpa III [16] and Zhang et al. [6]. In addition to the fresh concrete lateral pressure data measured experimentally, all variables of calculation, also measured by the authors, were collected.

Graphics on the pressure data versus the experimental measurements for the three studied methods were, likewise, produced.

The empirical data arranged by Maranhão [4] and O'Janpa III [16] were not used on the graphics because the placement rate values verified by these authors exceeded the restrictions determined by the ACI 347 R-04 (4.5 m/h for walls) and ABNT NBR 15696:2009 $(7 \mathrm{~m} / \mathrm{h})$, resulting in a situation where the predicted pressure were higher than the measured ones, making it impossible to graphically analyze the methods. 
The predicted pressure graphics versus the experimentally measured pressures are presented, for each method, on Figure 3, 4 and 5 . All of them present an inclination line of $1: 1$, which represents the position where the measured pressure are equal to the predicted pressure. The pressure data empirically collected were obtained by the placement rate which differ from 0.45 to $6.38 \mathrm{~m} / \mathrm{h}$, where these results were conducted on the calculation process. It is seen on the Figure 3 graphic that for the methods ACl 347 R-04 the dots, given by the ordered pairs of the predicted pressure and measured pressures, remained, mostly, sited on or below the line $1: 1$. This means that the presented standard conducted the predicted pressure values approximately equal to or higher than the actual concrete pressures exerted on the formworks. For two specific dots, exceptionally, the pressure were underestimated: in the first case the measured pressure was equal to $32.00 \mathrm{kPa}$ as for the predicted, the result was $30.00 \mathrm{kPa}$; in the second case, the measured pressure was equal to $39.00 \mathrm{kPa}$ and the predicted pressure was $35.80 \mathrm{kPa}$. On the dot located on the right side area of the graphic, the placement rate was $6.38 \mathrm{~m} / \mathrm{h}$, the measured pressure was $33.00 \mathrm{kPa}$ and the predicted one was $139.69 \mathrm{kPa}$, where the difference is around $223.32 \%$. As for the lower and distant dot on the line, the placement rate was equal to $5.17 \mathrm{~m} / \mathrm{h}$, the measured pressure was $17.10 \mathrm{kPa}$ and the predicted one $114.57 \mathrm{kPa}$, concluding that the overestimated pressure values (dots under the line $1: 1$ ) have exceeded by $469.98 \%$ the measured values.

On the graphic from Figure 4, it is highlighted that all dots are sited below the line 1:1, thus the CIRIA R 108 method conducted to predicted pressure results, overall, superior to the measured pressure results. For the most distant dot sited below the line 1:1 the measured value was $24.80 \mathrm{kPa}$ and the predicted one was $61.98 \mathrm{kPa}$, pointing to the conclusions that the overestimated pressure values exceeded up to $49.92 \%$ over the measured values, where the placement rate was equal to $1.97 \mathrm{~m} / \mathrm{h}$. About the two specific dots over the right side of the graphic, the calculated pressure was $72.00 \mathrm{kPa}$ while the measured ones were $33.00 \mathrm{kPa}$ and $47.70 \mathrm{kPa}$, where the placement rate was 6.38 e $2.36 \mathrm{~m} / \mathrm{h}$ with a difference from $18.18 \%$ to $49.06 \%$, respectively. It is notorious that for different placement rate values, the predicted pressure resulted in a single value. This situation has occurred because in the first case the pressure was calculated from equation (3), in which the placement rate is a variable criterion, and in the second case from the usage of the equation (4), which depends exclusively on the specific weight and the height of the concrete release.

It is verified on the graphic from Figure 5 , that the ABNT NBR 15696:2009 method has engendered pressure results approximately equal (the dos precisely placed on the line 1:1) or superiors than (the dots sited below the line 1:1) the measured pressure. Nevertheless it also conducted to pressure values nether than the experimental data (the dots placed above the line 1:1). For the dot which is positioned further down the line, the measured value was $17.10 \mathrm{kPa}$ and the predicted value was $82.18 \mathrm{kPa}$, leading to conclude that the overestimated pressure values exceeded around $280.61 \%$ the measured values, with a placement rate equal to $5.17 \mathrm{~m} / \mathrm{h}$. In cases where the pressure was underestimated, the upper dot above the line is about the measured pressure which is equivalent $27.50 \mathrm{kPa}$ and the predicted pressure is equal to $18.79 \mathrm{kPa}$. On the rightmost dot of the graphic, the placement rate

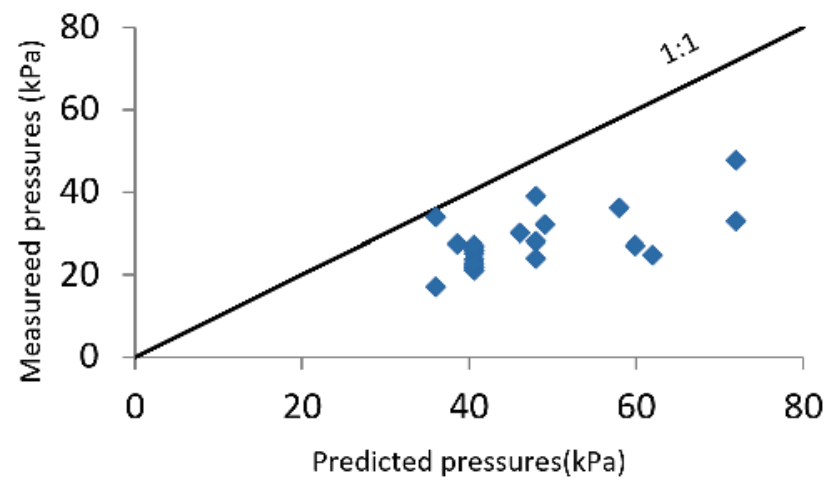

Figure 4

Lateral pressures predicted with the CIRIA R 108 method versus measured lateral pressures for placement rate between 0.45 and $6.38 \mathrm{~m} / \mathrm{h}$

Source: created by the authors

was $6.38 \mathrm{~m} / \mathrm{h}$, and the measured pressure was $33.00 \mathrm{kPa}$ with a predicted pressure values around $98.30 \mathrm{kPa}$, occasioning in a $97.88 \%$ difference.

It can be evidenced that, for the three different methods of prediction of the fresh concrete lateral pressure, the highest placement rate generated the highest calculated pressure value, notwithstanding it did not generated the greatest difference between the measured and the predicted pressure, indicating that, in addition to this perspective, other calculation variables, such as slump, unit weight, chemical composition as well as the concrete temperature must be important in the prediction of the pressure.

Comparing the $\mathrm{ACl} 347 \mathrm{R}-04$ to the other methods used in this report, it is acknowledged that, even though some of the results far exceeded the factual values of the pressure exerted on the formworks, this method can be considered a relevant standard for the prediction of the concrete lateral pressure, since, it presented, overall, a satisfying resemblance over the experimental data, for the rate values from 0.45 to $2.36 \mathrm{~m} / \mathrm{h}$. Analyzing the dots located below the line in the graphic of Figure 4, it is noticed

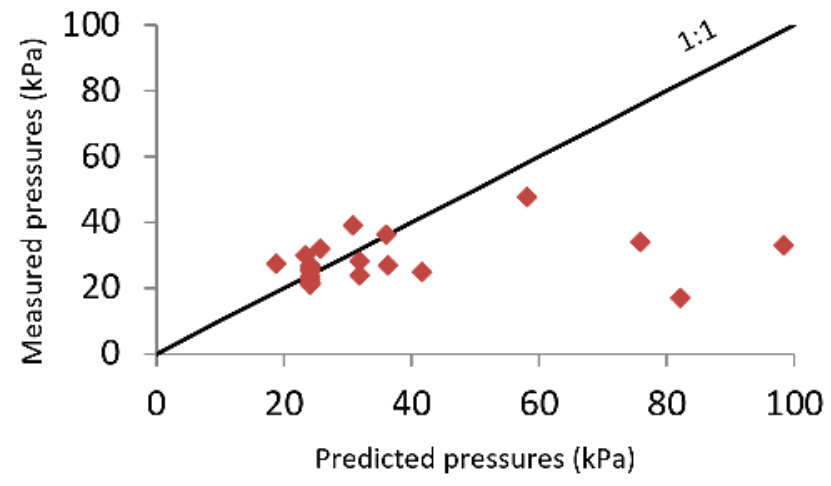

Figure 5

Lateral pressures predicted with the ABNT NBR

15696:2009 method versus measured lateral pressures for placement rate between 0.45 and $6.38 \mathrm{~m} / \mathrm{h}$

Source: created by the authors 
Table 2

Measured and predicted concrete lateral pressures

\begin{tabular}{|c|c|c|c|c|c|c|c|}
\hline \multirow[b]{2}{*}{ Author } & \multirow{2}{*}{$\begin{array}{l}\text { Cross } \\
\text { section } \\
\text { formwork }\end{array}$} & \multirow{2}{*}{$\begin{array}{l}\text { Dimensions } \\
(\mathrm{cm})\end{array}$} & \multirow{2}{*}{$\begin{array}{l}\text { Placement } \\
\text { rate } \\
(\mathrm{m} / \mathrm{h})\end{array}$} & \multirow{2}{*}{$\begin{array}{l}\text { Measured } \\
\text { pressures } \\
\quad(\mathrm{kPa})\end{array}$} & \multicolumn{3}{|c|}{ Predicted pressures (kPa) } \\
\hline & & & & & $\begin{array}{c}\mathrm{ACI} 347 \\
\mathrm{R}-04\end{array}$ & $\begin{array}{l}\text { CIRIA } \\
\text { R } 108\end{array}$ & $\begin{array}{c}\text { ABNT NBR } \\
15696: 2009\end{array}$ \\
\hline Maranhão [4] & Column & $20 \times 100$ & 32.00 & 26.38 & 565.06 & 57.60 & 419.58 \\
\hline O'Janpa III [16] & Wall & - & 27.40 & 2.40 & 366.52 & 68.22 & 468.96 \\
\hline O'Janpa III [16] & Wall & $e=24.13$ & 13.00 & 2.74 & 174.73 & 75.04 & 244.27 \\
\hline O'Janpa III [16] & Wall & $e=24.14$ & 12.20 & 2.45 & 163.15 & 68.22 & 225.56 \\
\hline O'Janpa III [16] & Wall & $e=22.86$ & 36.60 & 1.91 & 393.80 & 68.22 & 551.07 \\
\hline \multicolumn{8}{|c|}{$\begin{array}{l}\text { Source: created by the authors } \\
\text { 1) e is the wall thickness; } \\
\text { 2) The placement rate values were measured by the authors; } \\
\text { 3) The placing performed in Maranhão (2000) studies was executed manually, using manual concrete placeing, and the remaining ones used } \\
\text { concrete pumping. }\end{array}$} \\
\hline
\end{tabular}

that the CIRIA R 108 method, despite of overestimating the pressure for all cases, has conducted toward results more similar to the measured pressure values than the $\mathrm{ACl} 347 \mathrm{R}-04$ and the ABNT NBR 15696:2009 methods. Amongst all the three methods, the ABNT NBR 15696:2009 standard has developed the results with less accuracy.

The experimental data obtained by Maranhão [4] and O'Janpa III [16], as well as the predicted pressure results gathered by the $\mathrm{ACl}$ 347 R-04, CIRIA R 108 and the ABNT NBR 15696:2009 methods for the formworks used in the research, are documented on Table 2. It is evidenced on Table 2 that the pressure predicted from the placement rate values that exceed the limits established by the $\mathrm{ACl} 347 \mathrm{R}-04$ (up to $4.5 \mathrm{~m} / \mathrm{h}$ for walls) and the ABNT NBR 15696:2009 (up to $7.0 \mathrm{~m} / \mathrm{h}$ ) were extremely high.

In another perspective, the CIRIA R 108 method, despite of being the most conservative method, has conducted, as showed in the Table 2 data, to the lowest pressure values amongst the calculation of all three standards. It is relevant to emphasize that on the Table 2 , all the results obtained through this method were established by the relation $P_{\max }=\gamma_{c} . h$, because, as for the four situations, $C 1 \sqrt{v}$ was superior than $\mathrm{H}$. It is also observed, that even though it was not determined a maximum value for the placement rate, the CIRIA R 108 method limits this variation implicitly due to the formworks height $(\mathrm{H})$ and due to the coefficient $\mathrm{C}$.

\subsubsection{Analysis of the placement rate influence in the fresh concrete lateral pressure predicted through the theoretical methods}

The Figure 6 represents the graphic of the predicted pressure

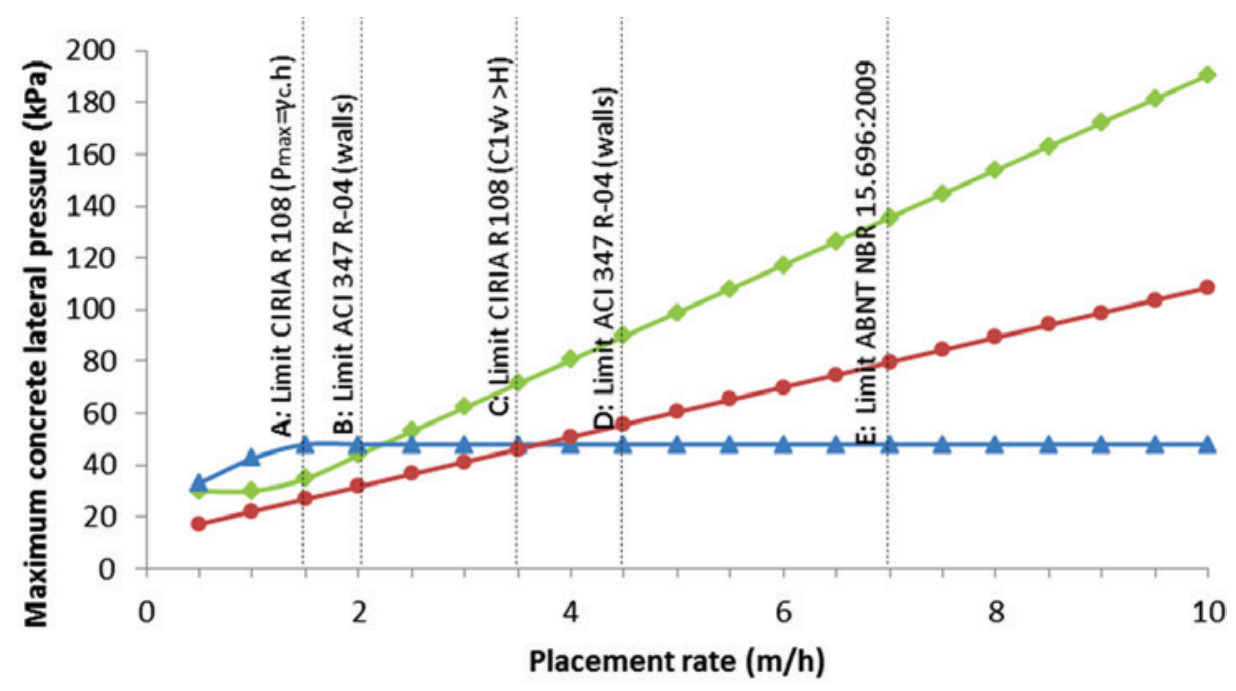

Figure 6

$\multimap$ ACI 347 R-04 $\multimap$ CIRIA R $108 \multimap$ ABNT NBR 15696:2009

Placement rate influence in the fresh concrete lateral pressure predicted from different methods of calculation source: created by the authors 
versus the placement rate, which demonstrates the influence of this variable over the fresh concrete lateral pressure calculated from the ACI 347 R-04, CIRIA R 108 and the ABNT NBR 15696:2009 methods. The vertical lines drawn $(A, B, C$, and $D)$ represent the placement rate limits for each one of these methods.

On the Figure 6, the effects of different placement rate values on the fresh concrete lateral pressure can be analyzed for a column with the presenting specified data: the height equal to $2.90 \mathrm{~m}$, concrete slump of $120 \mathrm{~mm}$, concrete temperature of $25^{\circ} \mathrm{C}$, unit weight equal to $24 \mathrm{kN} / \mathrm{m}^{3}$, ASTM Type I cement or CEM I (for the ascertainment of the concrete chemistry coefficient $\mathrm{C}_{c}$ e $\mathrm{C} 2$ ), which, in accordance with Mehta e Monteiro [17] and Waarde [13], respectively, corresponds approximately to the CP II cements, do not possess retardant additives for the setting period and the height of placing is around $2.00 \mathrm{~m}$. The placement rate diverged from 0.5 a $10.0 \mathrm{~m} / \mathrm{h}$, for each $0.5 \mathrm{~m} / \mathrm{h}$.

From the Figure 6 graphic, it was observed that the relation between the placement rate and the fresh concrete lateral pressure for the ABNT NBR 15696:2009 method is linear and directly proportional. On contrary, the ACl 347 R-04 method, presented a linear relation between the placement rate and the fresh concrete lateral pressure from up $2.0 \mathrm{~m} / \mathrm{h}$. Despite the fact that this method does not limit the placement rate for columns, it is evidenced that $2.1 \mathrm{~m} / \mathrm{h}$ (line $\mathrm{B}$ ) is the maximum limit for walls with concrete releasing height superior than $4.2 \mathrm{~m}$ and the minimum rate for the additional cases. For the placement rate values over than $4.5 \mathrm{~m} / \mathrm{h}$ (line $\mathrm{D}$ ) and $7.0 \mathrm{~m} / \mathrm{h}$ (line $\mathrm{E}$ ), which are the maximum values for the placement rate established by the ACl 347 R-04 method, for walls, and the ABNT NBR 15696:2009 method, does not possesses a single variation on the envelope comportment.

For the CIRIA R 108 method, it was verified, from the Figure 6, that the placement rate was directly proportional to the concrete lateral pressure over $1.5 \mathrm{~m} / \mathrm{h}$ (line A), maintaining its constancy from up to $2.0 \mathrm{~m} / \mathrm{h}$. This situation occurred because from up to $2.0 \mathrm{~m} / \mathrm{h}$ the pressure was obtained by $\gamma_{c} . h$, which was the lowest value between this equation and the value obtained from the equation (3). Therefore, the placement rate was limited to $1.5 \mathrm{~m} / \mathrm{h}$ in function of the height of placing $(\mathrm{h})$. Notwithstanding, the limit of the placement rate established by the equation (3) was equal to $3.5 \mathrm{~m} / \mathrm{h}$ (line $\mathrm{C}$ ), obtained due to the coefficient $\mathrm{C} 1$ equal to 1.5 (the crosstransverse form section of the column) and the column height $(\mathrm{H})$ equal to $2.90 \mathrm{~m}$. Therefore, in this method, the placement rate does not influence in the results of the pressure exerted by the concrete from its limited value, which corresponds to the placement rate in which $\gamma_{c}$. h becomes equal to the maximum pressure value or the point where $C 1 \sqrt{v}>H$.

Comparing the three theoretical prediction methods from information presented on the Figure 6 graphic, it is perceived that for the CIRIA R 108 method the concrete placement rate presented a greater impact on the pressure values up to $2.0 \mathrm{~m} / \mathrm{h}$, where from this exactly point the placement rate had developed intensively a greater influence on the values of pressure calculated by the $\mathrm{ACl} 347 \mathrm{R}-04$ method. From up to $4.0 \mathrm{~m} / \mathrm{h}$, the placement rate exerted greater influence on the pressure values predicted by the ABNT NBR 15696:2009 method, rather than the results obtained by the CIRIA R 108 standard.

\subsection{The design of columns formworks}

The designing of columns formworks, recommended by the $\mathrm{SH}$ Manual for Concrete Formworks, SH [18], is performed by analyzing each one of all component elements from the columns formworks: the mould (made of wood or plywood), the support (wooden or metal profile) and the mould (made of wood or metal profile with shoring bolts fixed with nuts).

The Figure 7 presents a column formwork with its respective elements: plywood plasticized with an $18 \mathrm{~mm}$ thick, 6x6 support wooden profile and yoke with metal profiles C-75.

In accordance with the SH [18], the design of columns formworks must be accomplished considering that the support panel pieces and the locks are elements simply supported, where the spans must be limited by the prediction of its deflection $(\mathrm{L} / 300 \mathrm{~mm})$ and also from the allowable bending moments of each piece.

From another perspective, the NBR 15696 [9] method establishes that the prediction of the formworks design and the shoring must be executed from the limit state design method. The method of allowable strength design can be performed, however, on ephemeral character, where the security factor utilized must assure the satisfaction of the same limit state design conditions. Albeit the formworks and the shoring are temporary structures, the combined actions to be considered in its execution ought to be the ones related to the normal building works, with all loads presumed as variables.

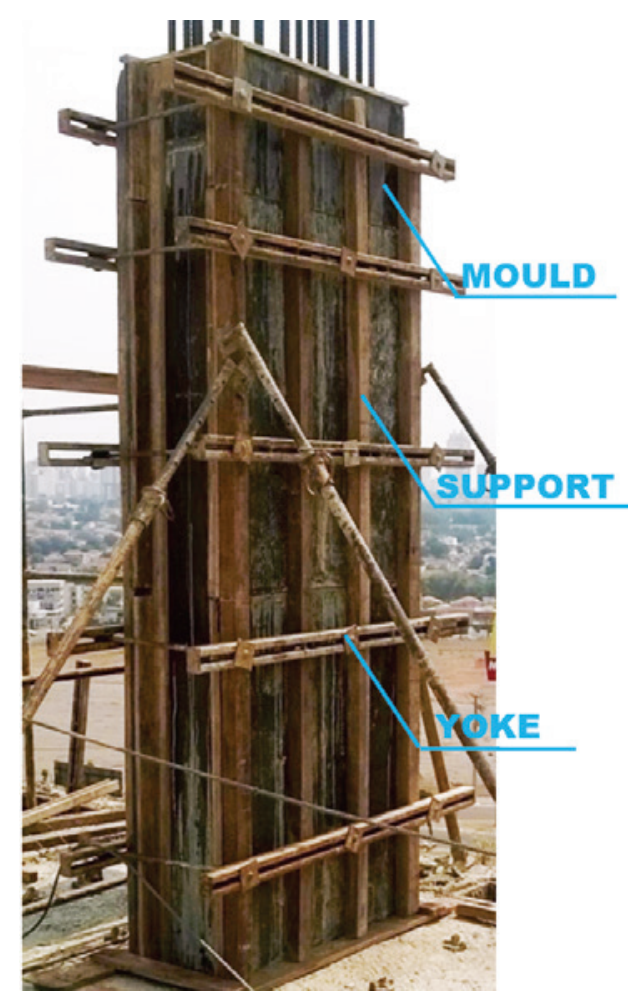

\section{Figure 7}

Constitutive elements of a column formwork

Source: created by the authors 
Table 3

Characteristics of the buildings and the columns studied

\begin{tabular}{|c|c|c|c|c|c|}
\hline Building & Type of building & $\begin{array}{c}\text { Concrete placement } \\
\text { method }\end{array}$ & $\begin{array}{c}\text { Column cross } \\
\text { section } \mathbf{( c m})\end{array}$ & $\begin{array}{c}\text { Cross section } \\
\text { shape }\end{array}$ & Formwork design \\
\hline A & Institutional & Isolated column & $30 \times 50$ & Column & No \\
\hline B & Residential & Monolithic method & $20 \times 130$ & Column & No \\
\hline C & Commercial & Isolated column & $35 \times 80$ & Column & No \\
\hline D & Residential & Monolithic method & $35 \times 15$ & Column & Yes \\
\hline E & Residential & Isolated column & $19 \times 695^{(1)}$ & Wall & Yes \\
\hline
\end{tabular}

Source: created by the authors

1) Column in section "U" with dimensions of $256 \times 19+183 \times 19+256 \times 19 \mathrm{~cm}$;

2) All supervised concrete placement were performed using concrete pumping;

3) In all buildings the concrete was made using the CP II cement.

\section{Materials and experimental program}

The research consisted in measuring the placement rate of columns in situ in order to determine the maximum pressure supported by the respective formworks.

\subsection{Measurements of the placement rate on the field}

It was collected measurements of placement rate in five building work places on Goiânia City, Goiás, Brazil, where for each one of the respective building work places, it was measured the placement rate from a column, which characteristics are described on the Table 3.

In two of the building work places it was performed the monolithic placing of slab, beam and column, method in which consists in the placing of the slab, beams and columns simultaneously. On the other building work places it was adopted the isolated column system, which consists in the execution of the columns separately, and sequentially, the slab and beams. Only two of the building work places had a design of formworks and shoring. To measure the placement rate values it was adopted three methods: one from the Associação Brasileira de Fôrmas, Escoramentos e Acesso (ABRASFE - Brazilian Association for Formworks, Shoring and Access) [19] and the measurements through the direct methodology, as well as the one through layers.

Table 4

Measurement results of the placement rate values collected in situ

\begin{tabular}{|c|c|c|c|c|c|c|c|}
\hline \multicolumn{2}{|c|}{ Column } & \multicolumn{4}{c|}{ Placement rate (m/h) } \\
\hline $\begin{array}{c}\text { Cross } \\
\text { section (cm) }\end{array}$ & Height (m) & $\begin{array}{c}\text { Filling time } \\
\text { (in minutes) }\end{array}$ & $\begin{array}{c}\text { Cross } \\
\text { section area } \\
\left(\mathbf{c m}^{2}\right)\end{array}$ & $\begin{array}{c}\text { Volume } \\
\left(\mathbf{m}^{3}\right)\end{array}$ & ABRASFE & Layers & Direct \\
\hline $30 \times 50$ & 3.48 & 0.84 & 1,500 & 0.52 & 243.97 & 235.33 & 248.57 \\
\hline $20 \times 130$ & 2.89 & 2.67 & 2,600 & 0.75 & 121.96 & 125.10 & 64.94 \\
\hline $35 \times 80$ & 2.90 & 2.16 & 2,800 & 0.81 & 98.21 & 92.18 & 80.56 \\
\hline $35 \times 175$ & 2.90 & 2.08 & 6,125 & 1.78 & 87.72 & 103.15 & 83.65 \\
\hline $19 \times 695$ & 3.90 & 14.45 & 13,699 & 5.34 & 24.25 & 21.05 & 16.19 \\
\hline
\end{tabular}

In addition to the measurements of the placement rate, it was performed the prediction of the maximum pressured supported by the columns formworks studied, from the estimated particularities and from the configurations of elements constitutive of the structuration panes, in accordance with the SH [18] and NBR 15696 [9] methods. For the measurements of the placement rate through the ABRASFE method, it was determined, initially, the volumetric flow rate of the pump. In order to execute this, it was measured with the assistance of a timer, the necessary time for the entire deflation of the concrete truck, discounting, accordingly, the pauses performed during the pumping. From the volumetric flow rate of the pump and from the column volume, it was established the time of the column filling. With the time of filling associated with the height of the column it was calculated the placement rate.

On the measurement of the layers, it was performed the methodology established by Billberg et al. [11], where it was used a measuring tape and a timer. Thus, it was verified, for each concrete layer placing inside the columns formworks, the depth of the surface with no concrete and the elapsed time until the concrete reached that specific level. The number of layers varied according to the amount of concrete that was necessary to the total filling of the column, differing, thus, for each building work places. For each one of the layers it was obtained a placement rate value. As final result, it was endorsed the highest of all values.

To measure the placement rate directly, it was obtained the 
required time by the total filling of the column, through the usage of a timer.

\subsection{Maximum pressure supported by formworks}

The maximum pressure supported by the column formworks studied in this research was calculated using the $\mathrm{SH}$ [18] and the NBR 15696 [9] methods from the arrangement of the formworks in situ. In order to achieve this, it was collected, at the building work places, the presenting data: the thickness of the plywood; the spans amongst supports of wood battens or of metal profiles; the dimensions of supports of wood battens or metal profiles; the spans amongst the yokes; as well as the dimensions of these yokes.

The data related to the mechanical properties of the plywood, the wooden battens and the yokes were obtained from the $\mathrm{SH}$ [18] tables.

It was embraced, for both methods that the pressure tolerated by the formworks is equal to the lowest values obtained for each column, i.e., the pressure supported by the less resistant element.

It was also predicted, for each column, the concrete lateral pressure, in accordance with the ACI347 R-04, CIRIA R 108 and the ABNT NBR 15696:2009 methods, where the placement rates were measured in situ.

\section{Results and discussions}

\subsection{Measurements of the placement rate}

The measurement results of the concrete placement rate are presented on the Table 4.

It is evidenced on the Table 4 that through the three methods of measurement it was obtained placement rate values superior than the values established as limits for the studied methods. The lowest value obtained was $16.10 \mathrm{~m} / \mathrm{h}$, which has exceeded in $137.57 \%$ the maximum value determined by ABNT NBR 15696:2009 (7 m/h) and it also has exceeded in $157.78 \%$ the placement rate value limit established for walls in accordance with the orientations of ACI 347 R-04 $(4.5 \mathrm{~m} / \mathrm{h})$. The highest placement rate value measured $(249.66 \mathrm{~m} / \mathrm{h})$ is 35.67 and 55.48 times higher than the established limits orientated by ABNT NBR 15696:2009 as well as for ACl 347 R-04, respectively.

The placement rates obtained by the layers method for column $35 \times 175 \mathrm{~cm}(103.15 \mathrm{~m} / \mathrm{h})$ and for the direct method for column 20 x $130 \mathrm{~cm}(64.94 \mathrm{~m} / \mathrm{h})$ and for walls $19 \times 695 \mathrm{~cm}(16.19 \mathrm{~m} / \mathrm{h})$, were not alike the others correspondent values. As it can be seen on the Table 4, there was a discontinuity in the placement rate values obtained by these two methods, as these had not flowed sequentially as expected to be inversely proportional to the cross section area and to the column volume. These mistakes may be justified by the fact that the placement rate was measured regardless any variation in the building methodologies applied at the building work places, which may cause the lack of accuracy in the procedures.

The Figure 8 and 9 present, respectively, the correlation of the cross section area and the column volume with the placement rate measured in situ.

The placement rate utilized in the graphics were obtained through the ABRASFE [19] method, due to the fact that they have present-

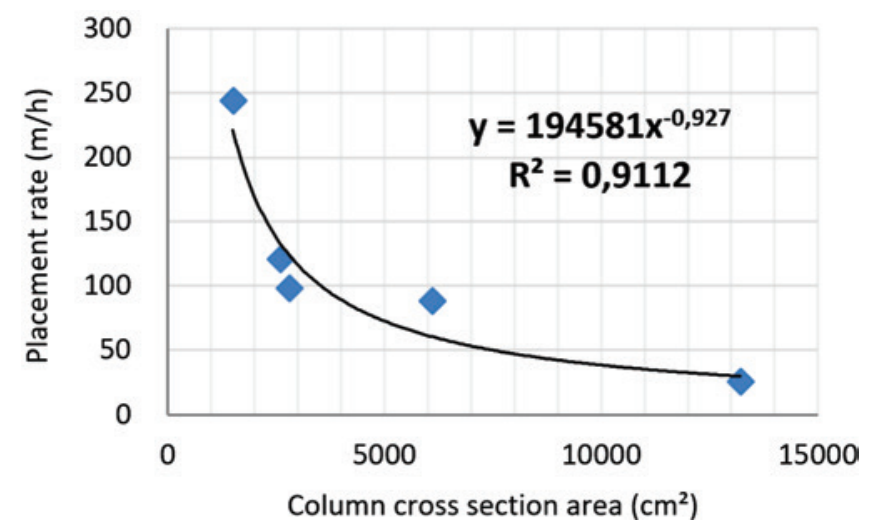

Figure 8

Relationship between the placement rates measured in situ and the cross section area of the columns

Source: created by the authors

ed a sequence of decreasing values for the respective cross section and volumetric increases.

It can be observed on the graphics from Figure 8 and 9 that there is a logical correlation between the placement rate and the cross section area and also between the placement rate and the columns volume.

To assure the accuracy of the equations found, it was used the following example from the ABRASFE [19] method: for a wall with cross section of $20.00 \times 0.50 \mathrm{~m}$ and height of $6.00 \mathrm{~m}$, the placement rate was $2.10 \mathrm{~m} / \mathrm{h}$, for the concrete releasing with the volumetric flow rate of the pump equal to $21 \mathrm{~m}^{3} / \mathrm{h}$. The cross section area of the wall is equal to $100,000 \mathrm{~cm}^{2}$ and the volume is $60 \mathrm{~m}^{3}$, resulting, respectively, on the placement rates of 4.51 and $3.24 \mathrm{~m} / \mathrm{h}$. It is also noticed that when the column volume is used as an input datum, the predicted placement rate approaches to the best measurement in situ if it is compared to the results obtained through the cross section area. It is also perceived that for the presenting example, the placement rate values established by the correlations with the cross section area and the column volume are, in this sequence,

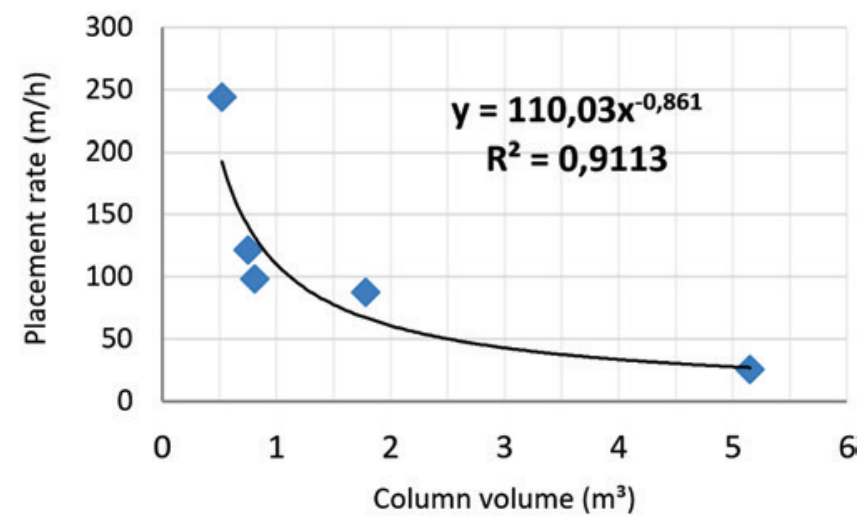

Figure 9

Relationship between the placement rates measured in situ and the columns volume

Source: created by the authors 
2.15 e 1.53 times higher than the results measured. It means that the values predicted by the correlations evidenced in the graphs of Figures 8 and 9 are in favor of safety since all the relations between fresh concrete lateral pressure and placement rate studied in this work are directly proportional, as shown in Figure 6.

Another observation performed through the Figures 8 and 9 is that the columns which height is equal or approximated to (2.89 and $2.90 \mathrm{~m}$ ), as showed in Table 4, the dots are sited close to each other in both graphics. This leads to conclude that the more columns with the same resemblance are monitored, the better it will be the obtained correlation between the columns characteristics and the placement rate. It was as well observed that if a greater amount of columns, with the most different dimensions, but with modest variations from one to another was studied, the distance between these dots will be smaller, as it occurred for the columns with same height. Besides, the dots have the same position distribution on both graphics, i.e., the relations found have a similar behavior, where both can be expressed by a power. Therefore, from a more detailed study, it may be possible to determine the placement rate by its volume or by the cross section area of the column, so that the prediction pressure and, consequently, the design of the formworks, are carried out in a more coherent execution with the reality of the building work places.

\subsection{Maximum pressure supported by the formworks}

The Table 5 presents the maximum pressures tolerance predicted, for each column, from the SH [18] and from the NBR 15696 [9] design methods as well as from the fresh concrete lateral pressure calculation standards studied by this report. The placement rate values used were obtained from the ABRASFE [19] method. The concrete temperature used for the study was established on $25^{\circ} \mathrm{C}$ (it was not measured in situ), presuming that on the experimental data presented by Arslan [14], Arslan et al. [15], Maranhão [4], O'Janpa III [16] and Zhang et al. [6], the concrete temperature did not surpassed $24{ }^{\circ} \mathrm{C}$ and on the prediction of fresh concrete lateral pressure, in accordance with NBR 15696 [9] methods it is not allowed to permit the temperature influence that exceeded $25^{\circ} \mathrm{C}$. Likewise, in accordance with the research executed by Gambale e Bittencourt [20], the temperature of the concrete made with CP II cements, does not exceed $25^{\circ} \mathrm{C}$ before 18 hours of concrete age. It is also noticed on Table 5 that, generally, the maximum pressure supported by the formworks predicted using the $\mathrm{SH}$ [18] method is superior to the result obtained from the recommended design criterions established by the NBR 15696 [9] method. It is emphasized that in the limit state method presented by the previous standard, the loads are increased and the resistance are reduced, which justifies, initially, the difference between the obtained values from the two prediction methods.

Equally on the Table 5, it is observed that in most cases, the plywood came to be the less resistant element when the dimensioning of the formwork was made through the $\mathrm{SH}$ [18] method, and the profile came to be the less resistant element when the dimension of the formworks were made using the NBR 15696 [9] method. In the situation of this wall, with measurements of $19 \times 695 \mathrm{~cm}$, the less resistant elements were the metal profile support, which supported up to $3.82 \mathrm{kPa}$, for the $\mathrm{SH}$ [18], and $0.45 \mathrm{kPa}$, and the NBR 15696 [9] methods. These are certainly quite small values for concrete lateral pressure, however, it is emphasized that on the empirical results of fresh concrete lateral pressures on walls obtained by O'Janpa III [16], and presented on Table 2, the values alternate from 1.91 to $2.74 \mathrm{kPa}$, with the placement rates approximated from 12.20 to $36.60 \mathrm{~m} / \mathrm{h}$, where these values measured from the placement rate values verified in situ for walls that are $19 \times 695 \mathrm{~cm}$ (from 16.19 to $24.25 \mathrm{~m} / \mathrm{h}$ ), as showed on Table 4, which it demonstrates coherence of the obtained results.

It is noticed that on Table 5 , the maximum pressure supported by the formworks from the SH [18] and the NBR 15696 [9] prediction methods, are the smaller than those established through the prediction methods of the fresh concrete lateral. The greatest difference was registered for the columns of $30 \times 50 \mathrm{~cm}$, with fresh concrete lateral pressure settled by the ABNT NBR 15696:2009 which exceeded 603.75 times the maximum pressure supported by the formworks predicted by the SH [18] simplified method. It can be interpreted by the fact the placement rates measured in situ, are far superior to the limits established by the standard calculation method.

The pressure predicted by the CIRIA R 108 method, for columns of $35 \times 80$ and $35 \times 175 \mathrm{~cm}$, had more approached to the maximum pressure tolerance established by the $\mathrm{SH}$ [18] method, coming up

Table 5

Maximum pressure supported by the column formworks

\begin{tabular}{|c|c|c|c|c|c|c|c|}
\hline \multirow[b]{2}{*}{$\begin{array}{c}\text { Cross } \\
\text { section }(\mathrm{cm})\end{array}$} & \multirow{2}{*}{$\begin{array}{l}\text { Predicted } \\
\text { pressure by } \\
\text { SH method } \\
(\mathrm{kPa})\end{array}$} & \multirow[b]{2}{*}{$\begin{array}{l}\text { Less resistant } \\
\text { elements }\end{array}$} & \multirow{2}{*}{$\begin{array}{c}\text { Predicted } \\
\text { pressure by } \\
\text { ABNT NBR } \\
\text { 15696:2009 } \\
(\mathrm{kPa})\end{array}$} & \multirow[b]{2}{*}{$\begin{array}{l}\text { Less resistant } \\
\text { elements }\end{array}$} & \multicolumn{3}{|c|}{ Predicted pressure (kPa) } \\
\hline & & & & & ACI 347 R-04 & CIRIA R 108 & $\begin{array}{c}\text { ABNT NBR } \\
15696: 2009\end{array}$ \\
\hline $30 \times 50$ & 3.90 & Yoke & 13.93 & Support & 819.33 & 83.52 & $2,354.63$ \\
\hline $20 \times 130$ & 20.31 & Plywood & 19.19 & Yoke & 680.42 & 69.36 & $1,176.57$ \\
\hline $35 \times 80$ & 41.83 & Plywood & 4.42 & Yoke & 682.78 & 69.60 & $1,142.94$ \\
\hline $35 \times 175$ & 34.93 & Plywood & 2.12 & Support & 682.78 & 69.60 & 854.56 \\
\hline $19 \times 695$ & 3.82 & Support & 0.45 & Support & 862.24 & 93.60 & 253.97 \\
\hline
\end{tabular}




\section{Table 6}

Placement rate values correspondent to the maximum pressure supported by the formworks predicted by the SH [18] simplified method

\begin{tabular}{|c|c|c|c|c|c|}
\hline \multirow{2}{*}{$\begin{array}{l}\text { Cross section } \\
\text { (cm) }\end{array}$} & \multirow{2}{*}{$\begin{array}{l}\text { Predicted } \\
\text { pressure by SH } \\
\text { method (kPa) }\end{array}$} & \multirow{2}{*}{$\begin{array}{c}\text { Measured } \\
\text { placement rate } \\
(\mathrm{m} / \mathrm{h})\end{array}$} & \multicolumn{3}{|c|}{ Predicted placement rate $(\mathrm{m} / \mathrm{h})$} \\
\hline & & & ACI 347 R-04 & CIRIA R 108 & $\begin{array}{c}\text { ABNT NBR } \\
\text { 15696:2009 }\end{array}$ \\
\hline $30 \times 50$ & 3.90 & 243.97 & -0.18 & 0.00 & -0.91 \\
\hline $20 \times 130$ & 20.31 & 121.96 & 0.71 & 0.11 & 0.73 \\
\hline $35 \times 80$ & 41.83 & 98.21 & 1.89 & 0.96 & 2.49 \\
\hline $35 \times 175$ & 34.93 & 87.72 & 1.51 & 0.59 & 2.19 \\
\hline $19 \times 695$ & 3.82 & 24.25 & -5.81 & 0.00 & -0.92 \\
\hline
\end{tabular}

with difference of $33.61 \%$ and $20.60 \%$, respectively, as presented on the Table 5.

With the maximum pressure supported by the formworks established by the SH [18] and NBR 15696 [9] methods it was calculated the respective placement rates from three fresh concrete lateral pressure calculus standards. The results are presented on the Tables 6 and 7 .

On the Tables 6 and 7 it is possible to notice that, for the maximum pressure values tolerated by the formworks, the placement rates are rather inferior than the measurements executed on the research in situ, where the data even had a negative values, in which most of the collected rates were smaller than the lowest limit established by the ACI 347 R-04 standards for wall, which is $2.1 \mathrm{~m} / \mathrm{h}$. It is possible, likewise, to emphasize that some of the placement rates from the Tables 6 and 7 satisfies the placement rate values to which were measured and predicted the concrete lateral pressure from the graphics of Figures 3, 4 and 5, which the values were from 0.45 to $6.38 \mathrm{~m} / \mathrm{h}$.

\section{Conclusions}

From the obtained results it was concluded that, for columns placed by concrete pumping, the placement rates measured at the five building work places from Goiânia City exceeded the values established by the ACI 347 R-04 and the ABNT NBR 15696:2009 methods, on this report, the placement rates measured were, respectively, 35.67 and 55.48 times superior to the established limits for placement rate values.

The placement rate values that were superior to the limits established by the prediction methods ACI 347 R-04 and ABNT NBR 15696:2009 engendered pressure values far superior to the results that possibly occurred over the formworks, being 603.75 times superior, as showed by the presenting research. Furthermore, the placement rate values relative to the maximum pressure values tolerated by the formworks established by the methods ACI 347 R-04, CIRIA R 108 and ABNT NBR 15696:2009 are rather inferior to the measurements collected in the experimental research performed in situ, where they could even reach negative values.

Since the maximum pressure values supported by the formworks estimated by the SH [18] and ABNT NBR 15696:2009 formwork design methods, are far inferior to the concrete lateral pressure values predicted with the placement rate measured in situ, it is possible to assure that the placement rate value from $16.19 \mathrm{~m} / \mathrm{h}$, the smallest placement rate value verified by the presenting report,

\section{Table 7}

Placement rate values correspondent to the maximum pressure supported by the formworks predicted by the limit state design in accordance with ABNT NBR 15696:2009

\begin{tabular}{|c|c|c|c|c|c|}
\hline \multirow[b]{2}{*}{$\begin{array}{l}\text { Cross section } \\
(\mathrm{cm})\end{array}$} & \multirow{2}{*}{$\begin{array}{c}\text { Pressure value } \\
\text { established } \\
\text { by ABNT NBR } \\
\text { 15696:2009 (KPa) }\end{array}$} & \multirow[b]{2}{*}{$\begin{array}{c}\text { Measured } \\
\text { placing }(\mathrm{m} / \mathrm{h})\end{array}$} & \multicolumn{3}{|c|}{ Predicted placement rate $(\mathrm{m} / \mathrm{h})$} \\
\hline & & & ACI 347 R-04 & CIRIA R 108 & $\begin{array}{c}\text { ABNT NBR } \\
15696: 2009\end{array}$ \\
\hline $30 \times 50$ & 13.93 & 243.97 & 0.37 & 0.01 & 0.09 \\
\hline $20 \times 130$ & 19.19 & 121.96 & 0.65 & 0.09 & 0.62 \\
\hline $35 \times 80$ & 4.42 & 98.21 & -0.15 & 0.00 & -0.63 \\
\hline $35 \times 175$ & 2.12 & 87.72 & -0.28 & 0.00 & -1.09 \\
\hline $19 \times 695$ & 0.45 & 24.25 & -6.45 & 0.00 & -1.26 \\
\hline
\end{tabular}


does not present a well-established correlation between the placement rate and fresh concrete lateral pressure value in the theoretical standards of prediction ACI347 R-04, CIRIA R 108 and ABNT NBR 15696:2009. This situation was also noticed on the performed analysis from the experimental data obtained by O'Janpa III [16], in which the lowest placement rate value was $12.20 \mathrm{~m} / \mathrm{h}$, with the corresponding measured fresh concrete lateral pressure equal to $2.45 \mathrm{kPa}$ and the values calculated, for this repport, were equal to $163.15 \mathrm{kPa}$ for the $\mathrm{ACl} 347 \mathrm{R}-04$ method, $68.22 \mathrm{kPa}$ for the CIRIA R 108 method and finally $225.56 \mathrm{kPa}$ for the ABNT NBR 15696:2009 method. Therefore, it is assured that the equations from all of these prediction methods are valid only for the placement rate limit values established by each one of them, leading to affirm that, it is essential the formulation of equation for the prediction of the fresh concrete lateral pressure at high levels of placing, in accordance with the current practices of the construction market. Likewise, it is possible to determine, for design purposes, the placement rate from its volume or from the column cross section area, obtaining, and more representative values than the ones that might occur on the building. The established equations used in this report, which represents such correlations, present determination coefficient equal to 0.91 , leading to a well-established approach between the placement rate values predicted and the ones measured in situ, where it was obtained by the column volume the best results if compared with the ones predicted from the cross section area. However, it is essential to be performed more research on this subject in order to obtain more data and, consequentially, establish a relation that is more representative of the many dimensions of columns and walls.

\section{References}

[1] FREITAS, N. D. B. Sistemas de cofragens racionalizadas e especiais para edifícios. 2011. 126 f. Dissertação (Mestrado) - Universidade da Madeira, 2011.

[2] REZENDE, R. B. Uma visão sobre o uso de fôrmas e escoramentos em cidades de grande, médio e pequeno porte do Brasil Central e as novas diretrizes normativas. 2010. 164 f. Dissertação (Mestrado) - Programa de Pós-Graduação em Engenharia Civil, Universidade Federal de Uberlândia, Uberlândia, 2010.

[3] NAZAR, N. Fôrmas e escoramentos para edifícios: critérios para dimensionamento e escolha do sistema. São Paulo: PINI, 2007. 173 p.

[4] MARANHÃO, G. M. Fôrmas para concreto: subsídios para a otimização do projeto segundo a NBR 7.190/97. 2000. 226 f. Dissertação (Mestrado) - Escola de Engenharia de São Carlos, Universidade de São Paulo, São Carlos, 2000.

[5] BARNES, J. M.; JOHNSTON, D. W. Fresh concrete lateral pressure on formwork. In: Construction Research Congress, 2003, Honolulu, Anais... Reston: ASCE, 2004.

[6] ZHANG, W.; HUANG J.; LI, Z.; HUANG, C. An experimental study on the lateral pressure of fresh concrete in formwork. Construction and building materials, v. 111, p.450-460, 2016.

[7] SANTILLI, A.; PUENTE, I, LOPEZ, A. Rate of placement discussion for the validation of experimental models of fresh concrete lateral pressure in columns. Construction and building materials, v. 24, p.934-945, 2010.
[8] LeEMANN, A.; HOFFMANN, C.; WINNEFELD, F. Pressure of self-consolidating concrete on formwork. Concrete International, v.8, n. 2, p. 27-31, 2006.

[9] ASSOCIAÇÃO BRASILEIRA DE NORMAS TÉCNICAS. ABNT NBR 15696:2009 : fôrmas e escoramentos para estruturas de concreto - projeto, dimensionamento e procedimentos executivos. Rio de Janeiro, 2009.

[10] CAUBERG, N.; DESMYTER, J.; PIÉRARD, J. Pousséedubétonautocompactantsurlescoffrages. Les Dossiers $d u$ CSTC, v.3, n.7, p. 1-15, 2006.

[11] BILLBERG, P. H.; ROUSSEL, N.; AMZIANE, S.; BEITZEL, M.; CHARITOU G.; FREUND, B.; GARDNER, J. N.; GRAMPEIX, G.; GRAUBNER, C. A.; KELLER, L.; KHAYAT, K. H.; LANGE, D. A.; OMRAN, A. F.; PERROT, A.; PROSKE, T.; QUATTROCIOCCHI, R.;VANHOVE, Y. Field validation of models for predicting lateral form pressure exerted by SCC. Cementand concrete composites, v. 54, p. 70-79, 2014.

[12] AMERICAN CONCRETE INSTITUTE. ACI 347 R-04: Guide for formwork for concrete. ACl, 2004.

[13] WAARDE, F. Formwork pressures when casting self compacting concrete. 2007. 149 f. Dissertação (Mestrado) - Concrete Structures Faculty of Civil Engineering Technical University of Delft, Delft, 2007.

[14] ARSLAN, M. Effects of drainer formworks on concrete lateral pressure. Construction and building materials, v. 16, p. 253259, 2002.

[15] ARSLAN, M.; SIMSEK, O.; SUBASI, S. Effects of formwork surface materials one concrete lateral pressure. Construction and building materials, v. 19, p. 319-325, 2005.

[16] O'JANPA III, J. V. Lateral pressures of fresh concrete on wall formwork under high rates of placement. Faculty of North Carolina State University, Raleigh, 2005. 123 p.

[17] MEHTA, P. K.; MONTEIRO, P. J. M. Concreto: microestrutura, propriedades e materiais. São Paulo: IBRACON, 2008. $674 \mathrm{p}$.

[18] SH Fôrmas, escoramentos e andaimes. Manual SH de fôrmas para concreto e escoramentos metálicos. São Paulo: PINI, 2008. 287 p.

[19] ASSOCIAÇÃO BRASILEIRA DE FÔRMAS, ESCORAMENTOS E ACESSO. Pressão do concreto fresco sobre as fôrmas. 34 slides, color. Acompanha texto. Disponível em: $<$ http:// livrozilla.com/doc/21923/--abrasfe>. Acesso em: 14 mai. 2016.

[20] GAMBALE, E. A.; BITTENCOURT, R. M.Análise do Fenômeno Térmico em Concreto com cimento Porthand Branco. In: Congresso Brasileiro do Concreto, 50., 2008, Salvador. Anais... São Paulo: IBRACON, 2008. 